\title{
Socioeconomic determinants of schistosomiasis in an urban area in the Northeast of Brazil
}

\author{
Ricardo Ximenes, ${ }^{1}$ Brian Southgate, ${ }^{2}$ Peter G. Smith, ${ }^{2}$ \\ and Leonardo Guimarães Neto ${ }^{3}$
}

ABSTRACT Objective. To identify and quantify the socioeconomic determinants of schistosomiasis in the urban section of São Lourenço da Mata, a town in the Northeast of Brazil.

Methods. A cross-sectional study was carried out in 1988 to measure the prevalence of schistosomiasis in São Lourenço da Mata among individuals aged 10-25 years and to estimate the socioeconomic characteristics of the households of those individuals. Household aggregation was tested. The data were analyzed on two levels, the family level and the individual level. On the family level we estimated the odds ratios for the association of schistosomiasis and socioeconomic variables related either to the head of the family or to the household. On the individual level we investigated if for the infected individuals there were differences in the intensity of infection (mean egg count) for the different levels of the socioeconomic variables.

Results. We found a significant degree of household aggregation of schistosomiasis (allowing for sex and area of residence (neighborhoods with similar socioeconomic conditions, according to census data)). In the analysis on the family level, better socioeconomic indicators for the place in the productive process (occupation, economic sector, and position in production of the head of the family, plus family income) and better socioeconomic indicators for patterns of consumption (level of education of the head of the family, type of housing, household possessions, water supply for the home, sanitation (that is, excreta collection), and family access to medical care) were all associated with a lower risk of schistosomiasis. The estimation of the probability of schistosomiasis for different levels of the socioeconomic variables showed a lower risk (0.072) for individuals whose households were at the top (best) levels of the indicators relative to the risk (0.715) for individuals whose households were at the baseline (lowest) levels of the indicators. Infected individuals whose families had better socioeconomic conditions had lower mean egg count values.

Conclusions. Control measures that may have a long-term effect, such as improvements in the water supply and sanitation, should be strongly encouraged. The theoretical reduction that we found in the probability of being infected if water supply and sanitation were improved highlights the importance of these measures. Implementing them would have a more permanent effect on the control of schistosomiasis and would also result in other benefits to the population.

Key words Schistosomiasis, socioeconomic factors, risk factors, urban health, Brazil.

1 Universidade Federal de Pernambuco, Departamento de Medicina Tropical, Recife, Pernambuco, Brazil. Send correspondence to: Ricardo Ximenes, Mestrado de Medicina Tropical, Bloco A - Hospital das Clínicas, Universidade Federal de Pernambuco, Av. Moraes Rêgo s/n, Cidade Universitária, Recife, PE, Brazil CEP: 50670 - 420; telephone and fax: 005581 - 2718527/2718514; e-mail: rximenes@ elogica.com.br.

2 University of London, London School of Hygiene and Tropical Medicine, Department of Infectious and Tropical Diseases, London, United Kingdom.

3 Fundação Joaquim Nabuco de Pesquisas Sociais, Recife, Pernambuco, Brazil.
There is much evidence that socioeconomic conditions are strongly associated with mortality, morbidity, and disability rates in general, and for many diseases in particular. These ties 
have been explained differently over time and according to the current of thought. We will limit ourselves to a brief comment on the views of a few authors that are relevant to our investigation of the socioeconomic determination of schistosomiasis.

Bunge (1) places causation in a wider spectrum of determination and defends the idea that events are produced and conditioned in definite ways, though not necessarily in a causal manner. He argues that causal determination (determination of the effect by the efficient (external) cause) is only one among several categories of determination that occur in real processes. His views are behind the theoretical conceptualization of the work of epidemiologists (2-4). Weed (2), for instance, claims that an exclusive focus on cause may restrict the critical testing process and then may limit the ability of epidemiology to explain disease in all its complexity. The framework of our study is rooted in his ideas and in the work of some authors of so-called Latin American social medicine, mainly Laurell (5) and Breilh (3). We worked with a noncausal determinism to explain the complexity of the distribution of schistosomiasis in a specific population and area. Disease is not an individual biological phenomenon, but rather a social and biological phenomenon that occurs within a social setting. We assumed that the socioeconomic aspects are determinant and operate through a set of conditioning factors, or intermediate mechanisms, to have an impact on the risk of the disease. The objective of our study was to identify and quantify the socioeconomic determinants of schistosomiasis in the town of São Lourenço da Mata, Brazil.

Some of the socioeconomic determinants that we studied have been shown to be related to the risk of schistosomiasis (6-11). Most of these studies, however, analyzed just the univariate association between each variable and schistosomiasis. We intended to further explore the socioeconomic risk factors and their univariate relationship with schistosomiasis, to select and to assemble them in such a way that the risk of the disease could be related to different levels of a set of factors, and to estimate the probability of schistosomiasis when given a set of socioeconomic characteristics.

The location of our study, the town of São Lourenço da Mata, has several notable characteristics: (1) it is mainly urban and belongs to the metropolitan region of Recife (which is the capital of the state of Pernambuco), an area into which there has been substantial migration; (2) it is situated in a vast endemic area in the Northeast of Brazil and has a natural stream system feeding the Capibaribe River, where the snail intermediate host may be found; and (3) since the 1960s several efforts have been directed toward controlling the disease in that area.

Our hypothesis was that there is socioeconomic determination of schistosomiasis in São Lourenço da Mata, that is, that the distribution of schistosomiasis in that population does not occur in a random manner but that the socioeconomic structure produces and conditions it in a definite way.

\section{METHODS}

The data that we present in this paper are part of a broader project, which had several objectives and was divided into different parts. In one part of the project, which we discuss in this paper, a cross-sectional study was carried out in 1988 to measure the prevalence of schistosomiasis in São Lourenço da Mata among individuals in the age group of 10-25 years, to estimate the socioeconomic characteristics of the households of those individuals, and to investigate the association between the socioeconomic factors and schistosomiasis. In another part of the project a population-based casecontrol design was used to investigate the pattern of water contact and schistosomiasis (12) and the association between migration and schistosomiasis (13). Finally, a cross-sectional study was carried out to investigate the socioeconomic factors behind leisure water contact (12).

\section{General characteristics of the study population and area}

The town of São Lourenço da Mata is located $20 \mathrm{~km}$ from the center of the city of Recife. In 1986 there were an estimated 50124 persons living in the urban portion of the town (14).

The local snail intermediate host is Biomphalaria straminea, which lives in a variety of habitats, including streams, ponds, ditches, and swamps.

\section{Selection of the socioeconomic variables}

Two sets of socioeconomic variables were selected. The first set was chosen to characterize the study population according to its position in the productive process, while the second set would allow its characterization according to patterns of consumption.

With the first set, the selection of variables was related to two important points. One was that there were no studies for this area that led to an acceptable characterization of its social structure and that could be used as a basis for the analysis that we were considering in our research project. The second point was that, given the lack of consistent studies regarding social classes or social stratification in the area, we believed that it would be important to get to know the population of the urban portion of São Lourenço da Mata according to the position that the family or the individual had in the process of production.

The information used was mainly related either to the head of the family or to the household. We considered an individual in the age group of 10-25 years as belonging to the same socioeconomic group as the head of the family. We believed that it was true not only for those who were younger and/or were dependents of the head of the family but also for the individuals in this age group exercising economic activities (working), inasmuch as they were living in the same house and sharing the same environment as the head of the family. 
To characterize the study population according to the position in the productive process we adopted four basic classifications: (1) one concerning the position in production of the head of the family; (2) one regarding the productive sector in which the head of the family was working (with four subgroups); (3) one that took into account the type of occupation of the head of the family (with three subgroups); and (4) one that was based on the family income level (with four categories). This classification approach made it possible to have an acceptable approximation of the social stratification of the study area.

The classification of position in production had four subgroups: inactive and unemployed, employee, autonomous, and employer. ("Autonomous" indicates someone who exercises his economic activity either alone or in a family-type business, with no employer and with no wage employee under his or her command.)

The classification regarding the economic sector also had four subgroups: industry; tertiary (commerce and services); farming, forestry, and fishing; and inactive and unemployed.

The classification of the type of occupation had three subgroups: unskilled, all other occupations, and inactive and unemployed.

The classification of the income level had four categories, which were based on multiples of the Brazilian minimum wage. The four income subgroups were: less than 1 minimum wage, equal to or greater than 1 and less than 2 , equal to or greater than 2 and less than 5, and 5 and more. The Brazilian minimum wage is established for the entire country on a monthly basis. It is stated in the Brazilian constitution that it should be high enough to provide for the basic needs of a family, including food, clothes, transport, and housing. However, it has lost its value over time (15).

We also selected a second set of socioeconomic variables that are more connected with patterns of consumption: education (six levels), type of housing (four types), household possessions (four categories), water supply (three categories), sanitation (that is, excreta collection) (four categories), and access to medical care (three categories).

The first set of variables (occupation, economic sector, and position in production of the head of household plus family income) express relationships connected with the productive process, while the second set (level of education of the head of the household, access to medical care, type of housing, household possession, water supply, and sanitation) are more related to social status. However, the two sets are very much connected as property ownership (owning means of production) may be a major determinant of both sets.

We used a multistage random sampling procedure. The urban area of São Lourenço da Mata was divided into areas of residence, that is, neighborhoods with similar socioeconomic conditions according to census data. A random sample of households was then selected within each stratum (area), keeping the same sampling fraction for every stratum and thus ensuring the same proportion of houses for every area. The questionnaire to collect information on the two sets of variables described above was applied to the woman head of the household (see the next subsection, on data collection). The parasitological diagnosis of schistosomiasis was performed for every individual aged 10-25 years in the household since prevalence of infection in most areas endemic for schistosomiasis is generally greatest among those 10-24 years old (16).

\section{Data collection}

We selected four interviewers-two males and two females-plus a specimen (feces sample) collector. Considering the type of information needed and considering that the woman head of the household would more easily be contacted and would be able to provide information of good quality, she was selected to answer the questionnaire designed to collect information on the two sets of variables described above. We defined the female head of the household as: (1) the spouse of the head of the household or (2) the woman who was the breadwinner or (3) the woman who was in charge of domestic work and the upbringing of the children (when there was no spouse or partner but there was a woman in the family). When there was not a woman head of the household, which happened in very few cases, the male head of the household was interviewed.

The fieldwork was carried out in 1988, over a period of 9 months. The data processing and the data analysis of the entire project, including for the information presented in this paper and for the information in two other papers $(12,13)$, was performed in 1989 and 1990; our Discussion section of this article provides some updating of the situation since 1990.

\section{Data analysis}

We analyzed the data on two levels, the family level and the individual level. In terms of the family level, the socioeconomic indicators that we used refer to the family as a whole, and our first step was to determine if there was a family aggregation of schistosomiasis. The test of household aggregation proposed by Smith and Pike (17) was used because it is amenable to stratification, and thus the effect of sex and area of residence was taken into account. A Fortran IV computer program to test for family aggregation was available from Smith and Pike (17) (Smith was also a coauthor of this article).

We had family-level variables, the sampling was conducted on a family basis, and we found a significant degree of household clustering in schistosomiasis. Therefore, we conducted the analysis of the two sets of variables previously described on the family level. Unconditional logistic regression was used to estimate the parameters in the logistic model of the association between schistosomiasis and the socioeconomic variables, using generalized linear interactive modeling. 
Since our unit of analysis was the family, the outcome for each unit was a proportion: the number of individuals aged 10-25 years with schistosomiasis out of the total number of individuals in this age group within a household.

We estimated the odds ratios for the association of schistosomiasis and the socioeconomic variables against a baseline level. For the baseline level, we selected for each of the socioeconomic variables a level reflecting poorer conditions-unskilled, less than a minimum wage, illiterate, etc. For some of the variables the baseline was the largest group, and for most of them it was not small. Larger baseline groups have the advantage of providing more stable odds ratio estimates. We also calculated confidence intervals and $P$ values for the odds ratios and performed a likelihood ratio test. (The likelihood ratio test statistic is calculated by comparing the goodness of fit, measured by the deviance, for two models, the first excluding the parameters to be tested and the second including them. It may be tested for statistical significance using a chi-square test, with the degrees of freedom equal to the difference between the numbers of parameters in the two models.) Trend tests were performed for some socioeconomic variables.

To model the joint effect of several exposures we adopted a step-down procedure. It should be noted that variables excluded from the final multivariate model are not necessarily unimportant. We are dealing with intercorrelated variables, and since the coefficient for any variable in a logistic regression equation depends on the whole set of variables included in the model, the variables selected are those that have a closer association with and thus better express the association with schistosomiasis. We performed a test of interaction between some of the exposures selected in the multivariate analysis.

Multicollinearity may have occurred in our multivariate analysis. That happens when two or more regressors are highly correlated; that is, when one changes, there is a strong tendency for the others to change as well. In these cases it is difficult to dis- entangle the effects of the two (or more) regressors, and the standard errors may be large when both regressors are in the model, but there is no special problem in predicting the dependent variable (18).

The risk or probability of disease associated with different levels of the explanatory variables was calculated. This is possible when the logistic regression equation is applied to cohort or cross-sectional studies, or in casecontrol studies, when the sampling fraction is known (19). Three different levels of socioeconomic variables were considered. First, the probability of being infected in the baseline level of the socioeconomic variables was assessed, with the worst conditions for all the variables. Second, the probability of being infected in the baseline level of the socioeconomic variables, except for water supply and sanitation, was calculated. For water supply, instead of Category I (stream, river, or uncovered well), Category III (piped water inside the house) was used; for sanitation, instead of Level I (no sanitary facility), Level IV (connection with the city sewage system) was used. Third, the probability of being infected in the best-off (wealthiest) levels of the socioeconomic variables was calculated. Attributable risks for multiple factors-different levels of socioeconomic variables-were estimated. Comparing the results obtained in the second and third levels of the socioeconomic variables with the results from the baseline level allows us to estimate the theoretically possible effect from improving the water supply, sanitation, or other socioeconomic conditions.

In addition to conducting the analysis on the family level we carried out an analysis on the individual level, that is, we assessed if the intensity of infection in the individuals aged 1025 years varied according to socioeconomic risk factors. We examined whether the same socioeconomic factors were associated with the intensity of infection for those individuals. That is, we investigated for the infected individuals if there were differences in the intensity of infection for the different levels of the socioeconomic vari- ables. To explore this association we took just the individuals aged 10 to 25 years old who were positive for schistosomiasis, and we compared the mean number of Schistosoma mansoni eggs (eggs per gram of feces) in the different levels of the socioeconomic attributes. We applied a logarithmic transformation of the mean, and the analysis was carried out on the transformed values. To report the final results we transformed them back into the original units by taking the antilogs. We employed analysis of variance to examine if there were differences among the means of the groups corresponding to each level of the socioeconomic variables. A test for trend was used for some variables. Because the analysis of variance may confirm differences among the groups but does not tell which groups differ from which others, we used a multiple comparison test, the Duncan multiplerange test, to examine which groups differed from each other.

\section{Laboratory analysis}

For the diagnosis of schistosomiasis the Kato method (20) as modified by Katz et al. (21) was used. Two slides were prepared from each feces specimen, and the number of eggs counted on the slide was multiplied by 24 to obtain the number of eggs per gram. Two laboratory technicians performed the microscopic examination, and a third technician was responsible for preparing and allocating the slides to the technicians.

\section{RESULTS}

Out of 2864 building units in São Lourenço da Mata that were drawn, there were 1825 households with individuals aged 10 to 25 . In the analysis on the family level we used information collected from 1728 households, since five women who were the female head of the household did not respond to the questionnaire and the persons in 92 households declined to participate in the parasitological examination. 
There were 4039 individuals in the age group of 10-25 years who had a parasitological examination for schistosomiasis; the results were positive for 1044 of them (25.8\%). In 660 households there were one or more infected individuals. In terms of the sex distribution of schistosomiasis, there was a higher prevalence among males $(34.1 \%)$ than among females $(17.6 \%)$. No important differences emerged from a comparison of three age subgroups studied: the prevalence levels were $25.2 \%, 28.9 \%$, and $23.3 \%$ for those aged 10-14, 15-19, and 20-25, respectively. A variation in prevalence from one area of residence to another was found. Given those results, sex and area of residence were allowed for in the analysis of family aggregation.

\section{Family aggregation}

Table 1 presents the number of households (families) with different numbers of infected individuals, compared with the expected number given the hypothesis of no aggregation, allowing for sex and area of residence. Allowing for sex and area of residence, there was a significant degree of household aggregation $(P<0.001)$. Considering the finding of household aggregation and taking into account that the socioeconomic variables refer to the household (family), the individuals aged 10 to 25 years within a family became the more adequate unit of analysis. The outcome was a proportion: the number of individuals with schistosomiasis aged 10-25 years out of the total number of individuals in this age group within a household.

\section{Risk of infection of individuals aged 10-25 years within a family, according to family-level socioeconomic variables}

The risk of schistosomiasis infection among individuals aged 10-25 within the family was significantly associated with the occupation of the head of the household, economic sector of the head of the household, position in pro-

TABLE 1. Distribution of households according to the number of individuals infected with schistosomiasis, compared with the expected number given the hypothesis of no aggregation, allowing for sex and area of residence (neighborhood where the family lives), São Lourenço da Mata, Brazil, 1988a

\begin{tabular}{cccr}
\hline $\begin{array}{c}\text { No. of cases } \\
\text { per household }\end{array}$ & $\begin{array}{c}\text { Observed no. of } \\
\text { households ("O") }\end{array}$ & $\begin{array}{c}\text { Expected no. of } \\
\text { households ("E") }\end{array}$ & $(\mathrm{O}-\mathrm{E})^{2} / \mathrm{E}$ \\
\hline 0 & 1068 & 991.69 & 5.87 \\
1 & 435 & 528.33 & 16.49 \\
2 & 138 & 144.39 & 0.28 \\
3 & 44 & 41.22 & 0.19 \\
4 & 24 & 14.93 & 5.50 \\
5 & 11 & 5.28 & 6.20 \\
6 & 6 & 1.46 & 20.38 \\
7 & 2 & 0.68 & 2.14 \\
Total & 1728 & 1728.00 & 54.91 \\
\hline
\end{tabular}

a Test of household aggregation by Smith and Pike (17): $P<0.001$.

TABLE 2. Odds ratio and $95 \%$ confidence interval (CI) for schistosomiasis infection of individuals aged 10-25 years within a family, according to the occupation, economic sector, and the position in production of the head of the household and family income, São Lourenço da Mata, Brazil, 1988

\begin{tabular}{|c|c|c|c|}
\hline Variable & No. of families & Odds ratio & $95 \% \mathrm{Cl}$ \\
\hline \multicolumn{4}{|l|}{ Occupation } \\
\hline Unskilled & 190 & 1.00 & \\
\hline All other occupations & 994 & 0.48 & $0.39-0.59$ \\
\hline Inactive and unemployed & 541 & 0.62 & $0.50-0.78$ \\
\hline \multicolumn{4}{|l|}{$\begin{array}{l}\text { Likelihood ratio statistic }(\text { LRS) }= \\
45.2, \text { degrees of freedom } \\
\text { (df) }=2, P<0.01 ; \\
\text { no information on } 3 \text { families. }\end{array}$} \\
\hline \multicolumn{4}{|l|}{ Economic sector } \\
\hline Industry & 433 & 1.00 & \\
\hline Tertiary (commerce and services) & 704 & 0.74 & $0.61-0.88$ \\
\hline Farming, forestry, and fishing & 34 & 1.00 & $0.77-2.00$ \\
\hline Inactive and unemployed & 541 & 0.95 & $0.80-1.13$ \\
\hline $\begin{array}{l}\mathrm{LRS}=15.7, \mathrm{df}=3, P<0.01 \\
\text { no information on } 16 \text { families. }\end{array}$ & & & \\
\hline \multicolumn{4}{|l|}{ Position in production } \\
\hline Inactive and unemployed & 541 & 1.00 & \\
\hline Employee & 889 & 0.86 & $0.73-1.00$ \\
\hline Autonomous (self-employed) & 266 & 1.05 & $0.85-1.30$ \\
\hline Employer & 32 & 0.53 & $0.29-0.98$ \\
\hline LRS $=9.5, \mathrm{df}=3,0.01<P<0.05$ & & & \\
\hline \multicolumn{4}{|l|}{ Family income (minimum wages) } \\
\hline$x<1$ & 336 & 1.00 & \\
\hline $1 \leq x<2$ & 386 & 0.81 & $0.65-1.00$ \\
\hline $2 \leq x<5$ & 259 & 0.48 & $0.37-0.61$ \\
\hline$x \geq 5$ & 77 & 0.30 & $0.20-0.46$ \\
\hline $\begin{array}{l}\mathrm{LRS}=61.5, \mathrm{df}=3, P<0.001 \\
\text { no information on } 670 \text { families. }\end{array}$ & & & \\
\hline
\end{tabular}

duction of the head of the household, and family income (Table 2). Using a linear trend term for family income, the likelihood ratio statistic (LRS) was significant $(\mathrm{LRS}=58.0$, degrees of free- dom $(\mathrm{df})=1, P<0.001)$. When using the deviance and comparing the goodness of fit of two models (the first introducing the variables as categorical and the second by fitting a linear 
trend), the test of significance for departure from linearity was not significant. These results suggest that the decrease in the log odds with the increase in the minimum wage (family income) can also be adequately described using a linear trend.

A statistically significant association was found between schistosomiasis infection of individuals aged 10-25 within the family and the level of education of the head of the household (Table 3). Compared to the illiterate group, those families whose heads were literate but had completed no formal course of education experience the same risk of being infected (Table $3)$. For all other categories the risk was reduced, but for those families whose heads had completed university education the reduction was not statistically significant. This finding for university education was unexpected, but the confidence interval was wide since there were only 18 families in this category. The fitted model using a linear trend for education of the head of the household was highly significant $(P<$ 0.001 ), and so was the test for departure from linearity $(P<0.001)$.

Schistosomiasis infection among individuals aged 10-25 within the family was also significantly associated with family access to medical care (Table 3 ). At the time of the data collection the health care system in Brazil offered different services to different socioeconomic groups, so the access to a specific institution or service reflected broader socioeconomic differences.

There was also a statistically significant association between schistosomiasis among individuals aged 10-25 within the family and the type of housing, household possessions, water supply, and sanitation (Table 4).

A multivariate analysis was conducted using the socioeconomic variables that showed a statistically significant association with schistosomiasis in the univariate analysis. Using a step-down procedure, the variables shown in Table 5 were the ones that were retained in the final model. The effect of each variable in the model was then adjusted for the effect of the others and also controlled for area of residence. It is worth noting that the magnitude of the odds ratios for these exposures was smaller in comparison to the univariate analysis. This may have happened because of the intercorrelation between the variables, leading to multicollinearity.
The likelihood ratio statistic was not statistically significant when we examined the following two interactions: (1) occupation and level of education and (2) possessions inside the house and level of education. However, the interaction between occupation and household possessions was statistically significant $(P<0.01)$.

\section{Probability of infection of individuals aged 10-25 years within a family, according to family-level socioeconomic variables}

The model containing the interaction term between occupation and household possessions was used to estimate the probability of schistosomiasis among individuals aged 1025 within the family, given a set of family-level socioeconomic characteristics. According to that model, the probability of being infected for someone who is $10-25$ years old and belongs to a family in the baseline (lowest) level of all the socioeconomic variables is 0.715 . The baseline levels for those variables would be: the head of the family is an unskilled worker; the household has no basic household

TABLE 3. Odds ratio and $95 \%$ confidence interval $(\mathrm{CI})$ for schistosomiasis infection of individuals aged 10-25 years within a family, according to the level of education of the head of the household and family access to medical care, São Lourenço da Mata, Brazil, 1988

\begin{tabular}{|c|c|c|c|}
\hline Variable & No. of families & Odds ratio & $95 \% \mathrm{Cl}$ \\
\hline \multicolumn{4}{|l|}{ Level of education } \\
\hline Illiterate & 525 & 1.00 & \\
\hline Literate but no course of ed. completed & 257 & 1.06 & $0.87-1.29$ \\
\hline Primário (4 yr of schooling) completed & 490 & 0.49 & $0.40-0.59$ \\
\hline Ginásio (8 yr of schooling) completed & 142 & 0.32 & $0.22-0.46$ \\
\hline Secundário (11 yr of schooling) completed & 128 & 0.20 & $0.12-0.32$ \\
\hline College completed & 18 & 0.48 & $0.21-1.11$ \\
\hline \multicolumn{4}{|l|}{$\begin{array}{l}\text { Likelihood ratio statistic }(\text { LRS })=148.1 \text {, degrees of freedom } \\
(\mathrm{df})=5, P<0.001 ; \text { no information on } 168 \text { families. }\end{array}$} \\
\hline \multicolumn{4}{|l|}{ Access to medical care } \\
\hline City, state, or charity & 273 & 1.00 & \\
\hline INAMPS, IPSEP, trade union, company, and related ${ }^{\mathrm{a}}$ & 1329 & 0.67 & $0.55-0.80$ \\
\hline Private practice and privately financed group medical plan & 47 & 0.15 & $0.07-0.34$ \\
\hline LRS $=41.2 ; \mathrm{df}=2, P<0.001 ;$ no information on 79 families. & & & \\
\hline
\end{tabular}


TABLE 4. Odds ratio and confidence interval (Cl) for schistosomiasis infection of individuals aged 10-25 years within a family according to the type of housing, household possessions, water supply, and excreta collection, São Lourenço da Mata, Brazil, 1988

\begin{tabular}{|c|c|c|c|}
\hline Variable & No. of families & Odds ratio & $\begin{array}{l}95 \% \text { confidence } \\
\text { interval }\end{array}$ \\
\hline \multicolumn{4}{|l|}{ Type of housing: } \\
\hline Type II (mud, redbrick; cement or dirt floor) & 119 & 0.75 & $0.56-1.01$ \\
\hline Type III (redbrick; cement floor) & 1149 & 0.38 & $0.31-0.45$ \\
\hline Type IV (redbrick; floor of tile, marble, etc.) & 184 & 0.23 & $0.17-0.31$ \\
\hline \multicolumn{4}{|l|}{ Likelihood ratio statistic $($ LRS $)=151.4$, degrees of freedom $(\mathrm{df})=3, P<0.001$. } \\
\hline Category I (no refrigerator, TV set, or gas stove) & 93 & 1.00 & \\
\hline Category II (refrigerator and/or TV set and/or gas stove) & 459 & 0.56 & $0.41-0.78$ \\
\hline Category III (sewing machine and/or bicycle and/or fan and/or stereo set) & 1013 & 0.35 & $0.26-0.48$ \\
\hline Category IV (telephone and/or motorbike and/or car and/or air conditioning) & 163 & 0.16 & $0.11-0.25$ \\
\hline $\mathrm{LRS}=110.2, \mathrm{df}=3, P<0.001$ & & & \\
\hline \multicolumn{4}{|l|}{ Water supply } \\
\hline \multicolumn{4}{|l|}{$\begin{array}{l}\mathrm{LRS}=183.4, \mathrm{df}=2, P<0.001 ; \text { others:(several categories in the same period or } \\
\text { varying over time; rain water; etc.): } 4 \text {; no information on } 1 \text { family. }\end{array}$} \\
\hline \multicolumn{4}{|l|}{ Sanitation (excreta collection) } \\
\hline Level I (no sanitary facility) & 80 & 1.00 & \\
\hline Level II (sanitary facility but excreta conveyed to either still or flowing water) & 43 & 0.61 & $0.36-1.02$ \\
\hline Level III (excreta collected in pit or tank) & 1145 & 0.60 & $0.44-0.84$ \\
\hline Level IV (connection with the city sewage system) & 449 & 0.20 & $0.14-0.29$ \\
\hline LRS $=146.6, \mathrm{df}=3, P<0.001 ;$ no information on 11 families & & & \\
\hline
\end{tabular}

amenities (refrigerator, gas stove, or TV set); the water supply comes from a stream, river, or uncovered well; the household has no excreta collection facility; and the head of the family did not complete the primaria level of schooling (first 4 years of schooling). Thus, for every 1000 individuals whose household is in this situation 715 would be expected to be infected.

If the other baseline variables were kept the same but the water supply and sanitation were improved, the theoretical probability of an individual being infected would decrease noticeably. For instance, if excreta collection were improved to Level IV (household connection to the city sewer system) and the water supply were improved to Level III (piped water inside the house), the probability of being infected would be 0.477. Therefore, there is an excess of
238 infected individuals per 1000 that is associated with the absence of proper piped water inside the house and no connection with the city sewage system $((0.715-0.477) \times 1000=238)$.

Similarly, theoretical improvements in other socioeconomic variables would also dramatically decrease the probability of individuals being infected. In comparison to the 0.715 probability of infection with the baseline level for all the socioeconomic variables, that probability would be one tenth of that (0.072) for an individual in a household with the best level of household possessions, water supply, and excreta collection in combination with the head of the family working and not being an unskilled worker and with the head of the family having completed secundaria (the equivalent of high school).

\section{Intensity of infection for individuals}

For the individuals 10-25 years old who were infected we compared the geometric mean of $S$. mansoni eggs per gram of feces in the different levels of the socioeconomic attributes of the head of the household. We present in this paper the results obtained for those variables retained in the final model of the multivariate analysis.

The intensity of infection in the group 10-25 years old, according to the occupation of the head of the household, is shown in Table 6. The analysis of variance indicates that real differences exist for different occupations $\left(F_{2,1039}=4.35, P<0.05\right)$. The Duncan's multiple-range test was performed, and the results showed that for those individuals in a family where the head 
TABLE 5. Estimated odds ratio and confidence interval (CI) for the association of schistosomiasis infection of individuals aged 10-25 years within a family and different socioeconomic variables (adjusted for each other and for area of residence), 1988

\begin{tabular}{|c|c|c|}
\hline Variable & Odds ratio & $95 \% \mathrm{Cl}$ \\
\hline \multicolumn{3}{|l|}{ Occupation } \\
\hline Unskilled & 1.00 & \\
\hline All other professions & 0.71 & $0.55-0.92$ \\
\hline Unskilled and unemployed & 0.69 & $0.53-0.89$ \\
\hline \multicolumn{3}{|l|}{ Household possessions } \\
\hline Category I & 1.00 & \\
\hline Category II & 0.78 & $0.54-1.13$ \\
\hline Category III & 0.62 & $0.44-0.89$ \\
\hline Category IV & 0.57 & $0.35-0.95$ \\
\hline \multicolumn{3}{|l|}{ Water supply } \\
\hline Category I & 1.00 & \\
\hline Category II & 1.04 & $0.77-1.40$ \\
\hline Category III & 0.69 & $0.49-0.99$ \\
\hline \multicolumn{3}{|l|}{ Sanitation (excreta collection) } \\
\hline Level I & 1.00 & \\
\hline Level II & 1.51 & $0.81-2.81$ \\
\hline Level III & 1.21 & $0.83-1.77$ \\
\hline Level IV & 0.78 & $0.43-1.42$ \\
\hline \multicolumn{3}{|l|}{ Level of education } \\
\hline No course of ed. completed & 1.00 & \\
\hline Primario (4 yr of schooling) completed & 0.64 & $0.53-0.78$ \\
\hline Ginasio (8 yr of schooling) completed & 0.52 & $0.35-0.77$ \\
\hline Secundario (11 yr of schooling) completed & 0.40 & $0.24-0.66$ \\
\hline College completed & 0.93 & $0.39-2.24$ \\
\hline \multicolumn{3}{|l|}{$\begin{array}{l}\text { Area of residence } \\
\text { (neighborhood where the family lives) }\end{array}$} \\
\hline Area I & 1.00 & \\
\hline Area 2 & 4.64 & $2.76-7.79$ \\
\hline Area 3 & 1.29 & $0.70-2.35$ \\
\hline Area 4 & 1.40 & $0.78-2.54$ \\
\hline Area 5 & 0.93 & $0.56-1.57$ \\
\hline Area 6 & 0.01 & $\mathrm{NM}^{\mathrm{a}} \mathrm{NM}$ \\
\hline Area 7 & 2.15 & $1.27-3.64$ \\
\hline Area 8 & 1.78 & $1.10-2.87$ \\
\hline Area 9 & 0.81 & $0.46-1.40$ \\
\hline Area 10 & 1.27 & $0.73-2.22$ \\
\hline Area 11 & 0.59 & $0.69-1.25$ \\
\hline Area 12 & 0.02 & NM NM \\
\hline Area 13 & 0.67 & $0.36-1.25$ \\
\hline Area 14 & 1.26 & $0.69-2.30$ \\
\hline
\end{tabular}

${ }^{a} \mathrm{NM}=$ not meaningful. Area 6 and Area 12 have a very small number of families, thus yielding excessively wide confidence intervals, so their comparison with Area 1 is meaningless.

of the household was an unskilled worker the intensity of infection was significantly higher.

We examined the amount of variation in the mean egg count among the categories of level of education of the head of the household (Table 7). The analysis of variance indicated differences between the observed means $\left(F_{4,925}=4.20, P<0.01\right)$. However, according to Duncan's test, the mean egg count did not differ significantly among the five categories. The failure of Duncan's test to reject the null hypothesis may be related to the small sample size for the categories with a higher level of education of the head of the household. Given the sample size of these groups, the differences were not large enough to reveal themselves above the random variations. It should be remembered that Duncan's test starts testing the extreme differences of means (the largest and the smallest) and that if that result is not significant, the analysis is ended and it is concluded that there are no significant differences among any of the group of means (22). More informative in this case is the test for linear trend $\left(F_{1,663}=\right.$ 4.32, $P<0.05)$. The test for linear trend gives evidence overall of an effect of level of education. As it was significant we concluded that there was a constant proportional decrease in the mean egg count across the categories of level of education.

The differences in the mean egg count among the four categories of household possessions are presented in Table 8. The differences did not reach statistical significance, according to analysis of variance $\left(F_{3,1040}=2.41\right.$, $P>0.05)$. Nevertheless, a difference between Category IV and the other categories may have been "diluted" into nonsignificance (23). The interpretation of Duncan's multiple-range test is that Category IV differs from Category I and Category III. Duncan's test may find significant contrasts when the overall $F$ test is nonsignificant. The test for linear trend gives evidence overall of an effect of household possessions $\left(F_{1,1042}=5.52, P<0.05\right)$, with the data being compatible with a constant proportional decrease in the geometric mean across the categories of household possession.

Table 9 shows the intensity of infection for the individuals according to the water supply that their households had for domestic use. The analysis of variance showed that there were significant differences among the three categories $\left(F_{2,1040}=5.35, P<0.01\right)$. Duncan's test showed that the group with piped water inside the house had a significantly lower mean than did the two others. Testing for linear trend, the result was statistically significant $\left(F_{1,1041}=8.03, P<0.01\right)$.

There were changes in the intensity of infection in relation to the type of excreta collection of the households (Table 10) $\left(F_{3,1036}=3.21, P<0.05\right)$. When the differences between categories were analyzed with Duncan's test, the results indicated that the lowest mean (Level IV) and the highest 
TABLE 6. Intensity of schistosomiasis infection of individuals aged 10-25 years, expressed as the geometric mean of Schistosoma mansoni eggs per $\mathrm{g}$ of feces, according to the occupation of the head of the household, 1988

\begin{tabular}{|c|c|c|c|c|c|}
\hline $\begin{array}{l}\text { Occupation of head } \\
\text { of household }\end{array}$ & $\begin{array}{c}\text { No. of } \\
\text { individuals } \\
\text { infected }^{\mathrm{a}}\end{array}$ & $\begin{array}{c}\text { Geometric } \\
\text { mean }\end{array}$ & $\begin{array}{l}95 \% \text { confidence } \\
\text { interval }\end{array}$ & $\begin{array}{c}\text { Mean egg count } \\
\text { (logged data, } \\
\text { base 10) }\end{array}$ & $\begin{array}{l}\text { Duncan } \\
\text { grouping }\end{array}$ \\
\hline Unskilled & 168 & 123.0 & $97.4-155.4$ & 2.09 & $A$ \\
\hline All other occupations & 498 & 85.1 & $75.1-96.5$ & 1.93 & B \\
\hline Inactive and unemployed & 376 & 88.0 & $75.2-100.8$ & 1.94 & B \\
\hline
\end{tabular}

a The information on the occupation of the head of the family was missing for 2 individuals.

${ }^{\mathrm{b}}$ Means with the same letter are not significantly different.

TABLE 7. Intensity of schistosomiasis infection of individuals aged 10-25 years, expressed as the geometric mean of Schistosoma mansoni eggs per $\mathrm{g}$ of feces, according to the level of education of the head of the household, 1988

\begin{tabular}{|c|c|c|c|c|c|}
\hline $\begin{array}{l}\text { Level of education } \\
\text { of head of household }\end{array}$ & $\begin{array}{c}\text { No. of } \\
\text { individuals } \\
\text { infected }\end{array}$ & $\begin{array}{c}\text { Geometric } \\
\text { mean }\end{array}$ & $\begin{array}{l}95 \% \text { confidence } \\
\text { interval }\end{array}$ & $\begin{array}{l}\text { Mean egg count } \\
\text { (logged data, } \\
\text { base 10) }\end{array}$ & $\begin{array}{l}\text { Duncan } \\
\text { grouping }^{\mathrm{b}}\end{array}$ \\
\hline No course of ed. finished & 647 & 100.0 & $89.1-112.2$ & 2.00 & A \\
\hline Primaria (4 yr of schooling) completed & 219 & 83.2 & $69.5-99.6$ & 1.92 & $A$ \\
\hline Ginasio (8 yr of schooling) completed & 38 & 50.1 & $33.0-76.2$ & 1.70 & A \\
\hline Secundaria (11 yr of schooling) completed & 19 & 45.7 & 22.5-93.0 & 1.66 & A \\
\hline College completed & 7 & 40.7 & $15.0-111.0$ & 1.61 & A \\
\hline
\end{tabular}

a The information on the level of education of the head of the household was missing for 114 individuals.

${ }^{b}$ Means with the same letter are not significantly different.

TABLE 8. Intensity of schistosomiasis infection of individuals aged 10-25 years, expressed as the geometric mean of Schistosoma mansoni eggs per $\mathrm{g}$ of feces, according to household possessions, 1988

\begin{tabular}{|c|c|c|c|c|c|c|}
\hline Household possessions & $\begin{array}{l}\text { No. of } \\
\text { individuals } \\
\text { infected }\end{array}$ & $\begin{array}{l}\text { Geometric } \\
\text { mean }\end{array}$ & $\begin{array}{l}95 \% \text { confidence } \\
\text { interval }\end{array}$ & $\begin{array}{l}\text { Mean egg count } \\
\text { (logged data, } \\
\text { base 10) }\end{array}$ & \multicolumn{2}{|c|}{$\begin{array}{l}\text { Duncan } \\
\text { grouping }\end{array}$} \\
\hline $\begin{array}{l}\text { Category I (no refrigerator, TV set, } \\
\text { or gas stove) }\end{array}$ & 85 & 114.8 & $82.2-160.4$ & 2.06 & A & \\
\hline $\begin{array}{l}\text { Category II (refrigerator and/or TV set } \\
\text { and/or gas stove) }\end{array}$ & 346 & 85.1 & $73.0-99.2$ & 1.93 & A & B \\
\hline $\begin{array}{l}\text { Category III (sewing machine and/or bicycle } \\
\text { and/or fan and/or stereo set) }\end{array}$ & 568 & 95.5 & $84.6-107.8$ & 1.98 & A & \\
\hline $\begin{array}{l}\text { Category IV (telephone and/or motorbike } \\
\text { and/or car and/or air conditioning) }\end{array}$ & 45 & 58.9 & $42.6-81.3$ & 1.77 & & B \\
\hline
\end{tabular}

mean (Level II) differed significantly from each other. The test for linear trend was also statistically significant $\left(F_{1,138}=4.80, P<0.05\right)$.

\section{DISCUSSION}

Our results showing an association between schistosomiasis and socioeconomic conditions are consistent with the results obtained in other studies, mainly Farooq et al. (10), Costa et al. (7), and Barreto (8).

In the analysis we regarded an individual in the age group of 10-25 years as belonging to the same social group as the head of the family. We believe that this is true not only for those who are younger and/or dependents of the head of the family but also for individuals in this age group who themselves are exercising economic activities (working). That is because these individuals live in the same house and share the same environment as the head of the family. Our finding of household aggregation reinforces this point and is coherent with the hypothesis of our study.

There was an inverse association between schistosomiasis and both the socioeconomic variables that are more 
TABLE 9. Intensity of schistosomiasis infection of individuals aged 10-25 years, expressed as the geometric mean of Schistosoma mansoni eggs per $\mathrm{g}$ of feces, according to the family water supply for domestic use, 1988

\begin{tabular}{|c|c|c|c|c|c|}
\hline Water supply & $\begin{array}{l}\text { No. of } \\
\text { individuals } \\
\text { infected }^{\mathrm{a}}\end{array}$ & $\begin{array}{c}\text { Geometric } \\
\text { mean }\end{array}$ & $\begin{array}{l}95 \% \text { confidence } \\
\text { interval }\end{array}$ & $\begin{array}{l}\text { Mean egg count } \\
\text { (logged data, } \\
\text { base 10) }\end{array}$ & $\begin{array}{l}\text { Duncan } \\
\text { grouping }^{b}\end{array}$ \\
\hline \multicolumn{6}{|l|}{ Category I } \\
\hline $\begin{array}{l}\text { (stream, river, or uncovered well) } \\
\text { Category II }\end{array}$ & 131 & 114.8 & $87.8-150.1$ & 2.06 & A \\
\hline $\begin{array}{l}\text { (covered well, public standpipe, or } \\
\text { piped water but not inside the house) }\end{array}$ & 595 & 97.7 & $86.6-110.2$ & 1.99 & A \\
\hline \multicolumn{6}{|l|}{ Category III } \\
\hline (piped water inside the house) & 317 & 74.1 & $64.2-85.6$ & 1.87 & B \\
\hline
\end{tabular}

TABLE 10. Intensity of schistosomiasis infection of individuals aged 10-25 years, expressed as the geometric mean of Schistosoma mansoni eggs per $\mathrm{g}$ of feces, according to type of excreta collection of the household, 1988

\begin{tabular}{|c|c|c|c|c|c|c|}
\hline $\begin{array}{c}\text { Sanitation } \\
\text { (excreta collection) }\end{array}$ & $\begin{array}{c}\text { No. of } \\
\text { individuals }\end{array}$ & $\begin{array}{c}\text { Geometric } \\
\text { mean }\end{array}$ & $\begin{array}{l}95 \% \text { confidence } \\
\text { interval }\end{array}$ & $\begin{array}{l}\text { Mean egg count } \\
\text { (logged data, } \\
\text { base 10) }\end{array}$ & \multicolumn{2}{|c|}{$\begin{array}{l}\text { Duncan } \\
\text { grouping }\end{array}$} \\
\hline Level I (no sanitary facility) & 66 & 102.3 & $68.4-153.0$ & 2.01 & A & $\mathrm{B}$ \\
\hline $\begin{array}{l}\text { Level II (sanitary facility but excreta } \\
\text { conveyed to either still or flowing water) }\end{array}$ & 32 & 104.7 & $65.2-168.1$ & 2.02 & A & \\
\hline Level III (excreta collected in pit or tank) & 830 & 95.5 & $86.5-105.4$ & 1.98 & $A$ & $\mathrm{~B}$ \\
\hline $\begin{array}{l}\text { Level IV (connection with the } \\
\text { city sewage system) }\end{array}$ & 112 & 61.6 & $47.7-79.7$ & 1.79 & & B \\
\hline
\end{tabular}

a The information on excreta collection of the household was missing for 4 individuals.

${ }^{b}$ Means with the same letter are not significantly different.

related to the place the individual has in the productive process (occupation, economic sector, position in production, family income) and the socioeconomic variables that are more connected with the pattern of consumption (level of education of the head of the household, water supply, sanitation, and access to medical care). Therefore, different measurements of the socioeconomic structure consistently show a decrease in the risk of disease for those who are better off. The utilization of multiple factors allowed an estimation of the probability of schistosomiasis in different levels of the socioeconomic variables. That analysis showed a substantially lower risk (0.072) for individuals whose households were at the top level of the socioeconomic variables relative to those whose households had the baseline levels (0.715). Those figures in- dicate an excess of 643 infected individuals per 1000 among those in the baseline levels in comparison to those in the best levels $((0.715-0.072) \times$ $1000=643$ ).

Concerning the intensity of infection, for the socioeconomic variables studied, there was a general decrease in the geometric mean with better socioeconomic conditions. It should be stressed that there is no dispute that intensity of infection is related to morbidity.

It is worth considering the implications of our findings. The socioeconomic risk factors that we studied allow the identification of subgroups with greater risk of infection and, once infected, with higher intensity. Therefore, these risk factors could be used as a complementary or alternative way to identify those individuals with whom special retreatment and reexamination schedules should be implemented.
For instance, an antischistosomal drug could be given to all the individuals whose households belong to the bottom two levels of household possessions (Category I and Category II) and administered just to the infected persons among the households that are betteroff (Category III and Category IV). Any of the socioeconomic variables that showed a statistically significant association with schistosomiasis could be selected for this purpose. Reexamination and retreatment schedules could also vary accordingly, with shorter intervals for Category I and Category II, e.g., less than a year, and with longer periods for Category III and Category IV, e.g., 18 months or more.

It is well known that schistosomiasis control relying heavily on drug treatment may reduce transmission but rarely if ever eliminates it, and prevalence usually returns rapidly to pre- 
control levels (24). The situation may be aggravated by the lack of a continuing commitment to the schistosomiasis program, as has been the case in São Lourenço da Mata. The main focus of the schistosomiasis control program implemented in São Lourenço da Mata has been mass treatment. The interval between consecutive treatments has been quite irregular (1979, 1981, 1984, 1986, and 1995), and several years have elapsed since the last time antischistosomal chemotherapy was employed. In fact, it is hard to define the strategy that is now being adopted in relation to schistosomiasis control. In 1990 the Superintendency of Public Health Campaigns, which was responsible for the program in the state of Pernambuco, was abolished, and the Health Secretariat of the state of Pernambuco has not defined the guidelines for this program in the context of the health care decentralization that has been taking place in Brazil. Given that situation, control measures that may have a long-term effect, such as improvements in the water supply and sanitation, should be strongly encouraged. The theoretical reduction that we found in the probability of being infected if water supply and sanitation were improved highlights the importance of these measures. Implementing them would have a more permanent effect on the control of schistosomiasis and would also result in other benefits to the population. Notwithstanding, these control measures have never been a priority in this area.

Assuming that the distribution of schistosomiasis in São Lourenço da Mata does not occur in a random manner but that the socioeconomic structure produces and conditions it in a definite way, the measures taken to promote health and to control schistosomiasis-to paraphrase Virchowshould be medical and social. Nonetheless, changes either within the health sector or in a broader context are difficult to achieve. In the health sector in Brazil there has been a wide gap between the amount of financial resources allocated by the Government to personal and curative health services and those directed to basic services and prevention. In fact, the administrative decentralization of the health sector, which started in the last decade and is still taking place, is occurring with only minor changes in the model of health care, with this model being strongly influenced by the rationale of the private sector (25). The health system is not yet organized to meet the main health needs of the population. The decentralization of decisions has so far not led to a substantial control over economic resources at the local administrative level. Furthermore, a growth in privately financed group medical plans and private health services is occurring in parallel with the decrease in the role of the State in health care.

Given this reality, an alternative suggested by Laverack and Labonte (26) would be community empowerment, with greater equality in who has resources, authority, legitimacy, and influence. These authors propose, among other things, the development of local leadership, the development and strengthening of community organizations, and the development and strengthening of interorganizational networks and political action. In addition, since community organization may remain local in character, with little if any influence on public policies, the formation of coalitions for political action may make it possible to overcome the limitations of community organizations and to exert pressure for social reform and political change $(27,28)$.

So far, most of the countries that have achieved long-term control of schistosomiasis have been ones that experienced important socioeconomic changes, resulting in improved living conditions. Important achievements in schistosomiasis control occurred in Japan and Venezuela, countries with a high gross national product per capita, if compared to other countries where schistosomiasis is endemic. Relevant achievements in schistosomiasis control also took place in China, in parallel with a much wider transformation of the society and an intensive mobi- lization of the population on health issues. There is no doubt that changes have been occurring in the economy of the Northeast of Brazil since the 1960s, with a development of industry and commerce that is associated with an increasing level of urbanization. However, even with the creation and expansion of employment in the formal sector of the economy, it is estimated that in urban areas in that section of the country the informal sector accounts for between $30 \%$ and $45 \%$ of the economically active population (29). In fact, urban underemployment rates in the region are as high today as they were 30 years ago, when exportled cane sugar activities were almost the only source of income and employment in the Northeast (30).

One alternative might be to implement a national policy of inclusive regional development that would achieve social changes and improve the living conditions of disadvantaged groups. In Brazil there is an important concentration of economic resources, both geographically, with better conditions in the Southeast, and in terms of the population, with $20 \%$ of the population sharing in $50 \%$ of the gross national product and the poorest $20 \%$ having only $2 \%$ of that. The wage gap between the rich and the poor is one of the largest in the world (31). In the long term this model seems unsustainable, and changes have already started due to the demands of the population.

To implement such a policy, several steps would be fundamental. One would be to democratize the access to land and to knowledge. Brazil has never undertaken an important change in its land ownership structure, as has the Republic of Korea. Nor has Brazil ever democratized access to formal education, as was done in Japan. School attendance in Brazil is not compulsory and, among those who do start school, many of them drop out at a young age. Another step would be to support agriculture on small parcels cultivated by the owner or by his or her family, and to make investments that would increase the economic dynamism of the rural sector, given the difficulty of cre- 
ating jobs in the large urban areas of the country. A third measure would be to dislodge the inherited values of colonization (a mentality of submission) and of slavery and to emphasize solidarity rather than competition. Another step would be to increase investments in education and health and to provide both piped water and sewage system connections for most households (31). If particular socioeconomic positions make some occupants more vulnerable to schistosomiasis in São Lourenço da Mata, then socioeconomic changes such as the ones described above might lead to permanent control of the disease.

Acknowledgments. Financial support for this research was generously provided by the Social and Economic
Research Steering Committee of the Special Programme for Research and Training in Tropical Diseases (TDR) of the World Health Organization (United Nations Development Program/World Bank/World Health Organization). Ricardo Ximenes gratefully acknowledges a grant from the Conselho Nacional de Desenvolvimento Científico e Tecnológico of Brazil.

\section{REFERENCES}

1. Bunge MA. Causality and modern science. New York: Dover; 1979

2. Weed DL. On the logic of causal inference. Am J Epidemiol 1986;123(6):965-979.

3. Breilh J. Epidemiología, economía, medicina y política. México, D.F.: Fontamara; 1986.

4. Almeida-Filho N. Epidemiologia sem números: uma introdução crítica à ciência epidemiológica. Rio de Janeiro: Campus; 1989.

5. Laurell AC. Social analysis of collective health in Latin America. Soc Sci Med 1989;28(11): 1183-1191.

6. Nordbeck HJ, Ouma JH, Sloof R. Machakos project studies agents affecting health of mother and child in a rural area of Kenya. Trop Geogr Med 1982;34:193-203.

7. Costa MFFL, Rocha RS, Magalhães MHA, Katz N. A clinico-epidemiological survey of schistosomiasis mansoni in a hyperendemic area in Minas Gerais State (Comercinho, Brazil). I. Differences in the manifestations of schistosomiasis in the town centre and in the environs. Trans R Soc Trop Med Hyg 1985;79: 539-545.

8. Barreto ML. Epidemiology of urban schistosomiasis in Northeast Brazil. A case study in Santo Antonio de Jesus [Ph.D. dissertation]. London: London School of Hygiene and Tropical Medicine, University of London; 1987.

9. Farooq M, Nielsen J, Samaan SA, Mallah MB, Allam AA. The epidemiology of Schistosoma haematobium and S. mansoni infections in the Egypt-49 project area. 2 Prevalence of bilharziasis in relation to personal attributes and habits. Bull World Health Organ 1966;35:293318.

10. Brasil, Fundação Instituto Brasileiro de Geografia e Estatística-FIBGE. Censo demográfico 1980. Rio de Janeiro: IBGE; 1983.

11. Jordan P. Schistosomiasis-research to control. Am J Trop Med Hyg 1977;26(5):877-886.
12. Ximenes R, Smith $T$, Southgate B, GuimarãesNeto L. Social environment, behavior, and schistosomiasis in an urban population in the Northeast of Brazil. Rev Panam Salud Publica 2001;9(1):13-22.

13. Ximenes R, Smith T, Southgate B, GuimarãesNeto L. Migration and urban schistosomiasisthe case of São Lourenço da Mata, Northeast of Brazil. Rev Inst Med Trop Sao Paulo 2000; 42(4):209-217.

14. FIDEM-Fundação de Desenvolvimento da Região Metropolitana do Recife, Fundação de Informações para o Desenvolvimento de Pernambuco-FIDEPE, Secretaria de Planejamento. São Lourenço da Mata. Informações municipais. Recife: Recife Gráfica Editora Ltda.; 1982.

15. Brasil, Departamento Intersindical de Estatística e Estudos Sócio-Econômicos. Salário mínimo real Brasil 1940-2000 [Web page]. Available at: www.dieese.org.br/anu/2001/3/ pg51.pdf. Accessed 20 November 2003.

16. World Health Organization. The control of schistosomiasis. Geneva: WHO; 1985. (WHO Technical Report Series No. 728)

17. Smith PG, Pike MC. Generalisation of two tests for the detection of household aggregation of disease. Biometrics 1976;32:817-828.

18. Wonacott RJ, Wonacott TH. Introductory statistics. New York: John Wiley and Sons Inc.; 1985.

19. Schlesseman JJ. Case-control studies. Design, conduct, analysis. Oxford: Oxford University Press; 1982.

20. Kato K, Miura M. Comparative examinations. Kisechugaku Zasshi 1954;3:35.

21. Katz N, Chaves A, Pellegrino J. A simple device for quantitative stool thick-smear technique in schistosomiasis mansoni. Rev Inst Med Trop Sao Paulo 1972;14(6):397-400.

22. Bailar III, JC, Mosteller F. Medical uses of statistics. Westford, Massachusetts, United States: NEJM Books; 1986.
23. Healy JR, Osborn JF. Manual of medical statistics. Vol. II. London: London School Hygiene and Tropical Medicine, University of London; 1985.

24. Sturrock CK. The control of schistosomiasis: epidemiological aspects of reinfection. Mem Inst Oswaldo Cruz 84 1989;(Suppl.1):134-147.

25. Silva LMV. A research agenda for health policies and services in northeast Brazil. Cad Saude Publica 2000;16(3):857-861.

26. Laverack G, Labonte R. A planning framework for community empowerment goals within health promotion. Health Policy and Plan 2000;15(3):255-262.

27. Labonte R. Community and professional empowerment. Can Nurse 1989;85(3):22-28.

28. Labonte R. Community empowerment: the need for political analysis. Can J Public Health 1989;80(2):87-91.

29. Guimarães L, Souza, AV. A dinâmica do mercado de trabalho urbano no nordeste. In: Carvalho IMM, Haguete TMT, coords. Trabalho e condições de vida no nordeste brasileiro. São Paulo: Hucitec; 1984. Pp. 115-138.

30. Souza AV, Guimarães L, Araújo TP. Employment implications of informal sector policies: a case study of Greater Recife. Int Labour Rev 1988;123(2):243-258.

31. Araújo TB. Ensaios sobre o desenvolvimento brasileiro: heranças e urgências. Rio de Janeiro: Editora Revan; 2000.

Manuscript received 13 August 2002. Revised version accepted for publication on 10 July 2003. 
RESUMEN Objetivo. Identificar y cuantificar los factores socioeconómicos que determinan la esquistosomiasis en el área urbana de São Lourenço da Mata, población del nordeste de Brasil.

Determinantes socioeconómicos de la esquistosomiasis en un área urbana del nordeste de Brasil
Métodos. Se realizó un estudio transversal en 1988 para evaluar la prevalencia de esquistosomiasis en personas de 10 a 25 años de edad en São Lourenço da Mata y valorar las características socioeconómicas de los núcleos familiares de esas personas. Se evaluó la agregación de esos núcleos familiares. Los datos obtenidos se analizaron tanto en el nivel familiar como en el individual. En el nivel familiar se calcularon las razones de posibilidades de la asociación de la enfermedad con las variables socioeconómicas relacionadas con el jefe de la familia o con el núcleo familiar. En el nivel individual se investigó si había diferencias en cuanto a la intensidad de la infección (número promedio de huevos) según los diferentes niveles de las variables socioeconómicas de las personas infectadas.

Resultados. Se encontró un grado significativo de agregación de los núcleos familiares de las personas con esquistosomiasis (tomando en cuenta el sexo y la zona de residencia, es decir, vecindarios con condiciones socioeconómicas similares, de acuerdo con los datos censales). Según el análisis en el nivel familiar, una mejoría en los indicadores socioeconómicos relacionados con la posición en el proceso productivo (ocupación, sector económico y posición en la producción del jefe del núcleo familiar, más el ingreso familiar) y una mejoría en los indicadores socioeconómicos relacionados con los patrones de consumo (nivel de educación del jefe de la familia, tipo de vivienda, bienes que posee el núcleo familiar, suministro de agua en el hogar, instalaciones sanitarias para la eliminación de excrementos y acceso de la familia a la atención médica) se asociaban siempre con un menor riesgo de esquistosomiasis. El cálculo de la probabilidad de sufrir esquistosomiasis según los diferentes niveles de las variables socioeconómicas demostró un riesgo menor $(0,072)$ para las personas cuyas familias se ubicaban en los niveles superiores (mejores) de acuerdo con estos indicadores en comparación con el riesgo $(0,715)$ de las personas cuyos núcleos familiares se encontraban en el nivel más bajo según esos mismos indicadores. Las personas infectadas cuyo núcleo familiar tenía mejores condiciones socioeconómicas presentaron un menor número promedio de huevos en el organismo.

Conclusiones. Se debe estimular fuertemente la adopción de medidas de control que puedan tener efecto a largo plazo, tales como el mejoramiento del suministro de agua y de las instalaciones sanitarias. El efecto teórico encontrado de que la probabilidad de estar infectado disminuye cuando mejoran el suministro de agua y los servicios sanitarios subraya la importancia de estas medidas. Su implementación podría tener efectos más duraderos sobre el control de la esquistosomiasis y generar otros beneficios para la población. 